\title{
Cytoplasmic and Combining Ability Effects on Agro-Morphological Characters in Intra and Inter Crosses of Pima and Upland Cottons (G.Hirsutum and G. Barbadense)
}

\author{
Mohammad Reza Zangi (Corresponding author) \\ Sari Agricultural Sciences and Natural Resources University, sari, Iran, P. O.Box 578 \\ Cotton breeding Dep., Cotton Research Institute of Iran \\ Beheshti st., P.O.Box 49175-483, Gorgan, Iran \\ E-mail: mrzangi@yahoo.com \\ Nadali Babaeian Jelodar \\ Plant breeding and biotechnology Dep., University of Mazandaran, Babolsar, Iran \\ E-mail: nbabaeian@yahoo.com \\ Seid Kamal Kazemitabar \\ Plant breeding and biotechnology Dep., University of Mazandaran, Babolsar, Iran \\ E-mail: nbabaeian@yahoo.com \\ Mosarreza Vafaei-tabar \\ Cotton breeding Dep., Cotton Research Institute of Iran \\ Beheshti st., P.O.Box 49175-483, Gorgan, Iran
}

\begin{abstract}
Combining ability and heterosis were determined in a population obtained from the full diallel crossing of four different cotton genotypes (G. hirsutum and G. barbadense) for agro morphological traits and yield. High variation was observed for characteristics among parents and the F1 combinations. So, selection could be done for improved yield, yield components and agro morphological traits. Barbadense 5539 and Termeze14 (G. barbadense) had positive GCA for height, bolls/plant and sympodia branch/plant, Inverse, Sahel and Sepid (G. hirsutum) had negative GCA for these characteristics. G. barbadense genotypes showed negative GCA for monopodia branch/plant, sympodia branch length and boll weight, Inverse, G. hirsutm genotypes was observed positive GCA for this traits. The GCA: SCA ratios for the studied traits were higher than one indicating the presence of additive genetic effects for most of the characteristics studied, except for sympodia branch length.
\end{abstract}

Keywords: Cotton, General combining ability (GCA), Specific combining ability (SCA), Intra and Inter specific crosses, Maternal effects

\section{Introduction}

Cotton (Gossypium spp) the worlds' most important natural source of fiber is comprised of about 50 diploid and tetraploid species. Commercial cotton fiber is produced from only four species: two diploids G. arboretum L. ( $\mathrm{n}=13$, A2A2) and G. herbaceum L. (n=13, A1A1) and two tetraploids G. barbadense (n=26, AAD2D2 genome) and G. hirsutum L. (n=26, AAD1D1 genome (Vafaie-tabar et al. 2004).

Upland cotton, G. hirsutum, dominates the worlds' cotton fiber production, representing $90 \%$ of the production. Compared with the upland cotton, the second most cultivated species, G. barbadense, has superior fiber length, strength, and fineness. G. hirsutum varieties, however, are usually early- maturing and higher yielding (Lacape et al.2005). 
Upland cotton (Gossypium hirsutum L) is the most extensively cultivated of the four cultivated Gossypium species, and, as such, it has been the target of numerous genetic studies and breeding efforts. The level of genetic diversity is low in G. hirsutum, especially among agriculturally elite types, as revealed by all means of assessment (Gutiefrrez et al. 2002; Ulloa and Meredith 2000; wendel et al. 1989).

Gossypium barbadense (L.) is the only 52- chromosome relative of upland cotton (G. hirsutum, $2 \mathrm{n}=52$ ) that is cultivated. It is valued for its fiber length and quality, whereas upland cotton is more valuated for its high yield (Saha et al. 2006).

Most genetic traits useful for cotton improvement are influenced by several genes. These are called quantitatively inherited traits (Shappley et al., 1998). The identification and characterization of genes controlling traits of use in plant improvement has long been a focus of scientists in the agricultural community. Cotton is the most important textile fiber crop and the worlds' second-most important oil-seed crop after soybean (Poehlman and Sleper, 1995). It is grown commercially in the temperate and tropical region of more than 50 countries, including the United States, India, China, central and South America, The Middle East, and Australia (Fryxell, 1979; Smith, 1999).

Increasing diversity is therefore essential to genetic improvement efforts. Each of the three major approaches to increasing genetic diversity (mutagenesis, germplasm introgression, and transformation) has advantages and disadvantages. Interspecific germplasm introgression is particularly attractive in that it utilizes abroad germplasm base, can be targeted to one or more specific traits or genes or modulated to include thousands of genes or even entire genomes. However, the biological and technical challenges of introgression increase as the phyletic distance between the donor and recipient genome increases (Saha et al. 2006).

Diallel crossing technique in cotton has been used by cotton breeders. Baloch et al. (1995) revealed the importance of specific combining ability for yield, 100- seed weight and lint percentage, and general combining ability for boll number per plant and lint percentage. Wilson (1991): Tang et al.(1993) and Nadeem et al. (1998) reported significant general and specific combining ability effects for lint yield, lint percentage, seed cotton weight per boll and boll number per plant.

Hybrid vigor in cotton has been observed in interspecific crosses as well as in crosses between varieties within the species. Fryxell et al. (1958), Hutchinson et al. (1938), Marani (1967), Stroman (1961), and Ware (1931) in particular showed that crosses between G. barbadense and G. hirsutum were much more productive than either parent. Because of the differences in the characteristics of the lint of the two species, it frequently has objectionable qualities in the hybrid. This problem is less likely to arise in intraspecific hybrids where considerable hybrid vigor has also been shown.

In a molecular analysis of $G$. hirsutum introgression into Pima (G. barbadense) cotton, $7.3 \%$ of the alleles of Pima cultivars were found to be derived from G. hirsutum (Wang et al., 1995). These alleles were not randomly distributed within the G. barbadense genome, since nearly $60 \%$ of the total introgression was found within five specific chromosomal regions accounting for less than $10 \%$ of the genome.

Transfer of reniform nematode resistance from G. Longicalyx into G. hirsutum requires introgression of genes from the unique diploid F genome of G. Longicalyx into either the A or D sub genome of allotetraploid G. hirsutum. As bridges, two synthetic tetraploid triple species hybrids, referred to as HLA and HHL, were developed (Bell and Robinson, 2004). Robinson et al. (2007) was studied two trispecies hybrids of G. hirsutum, G. longicalyx and either G. armourianum Kearney or G. herbaceum L. to introgress high resistance to the nematode from G. Longicalyx into G. hirsutum. Introgression was pursued from 28 resistant $\mathrm{BC} 1$ plants, each of which was backcrossed four to seven times to $\mathrm{G}$. hirsutum to derive agronomically suitable types.

The objective of this study was to estimate parental general combining ability effects, to compare performance among F1 hybrids, and to identify those superior for yield and agro morphological traits.

\section{Material and Method}

During the summer of 2005, four different cotton genotypes, Thermez 14 (line 2) and barbadense 5539 (line 18) of G. barbadense species, Sepid (line 22) and Sahel (line 13) of G. hirsutum species, were crossed to produce F1 seeds. These genotypes display a continuous spectrum of morphological traits between the two parental species (Ulloa et al., 2000). Parents and F1 seed was planted in the spring of 2006. Four parents and 12 hybrids were planted in randomized complete blocks. Plots consisted of four, $10 \mathrm{~m}$ - long row with $80 \mathrm{~cm}$ apart. Soil was a silt- loam. Plant density was about 33000 plants ha-1. Weed control, irrigation, and insect control were standard practices for production of cotton in the Hashemabad cotton research station, Gorgan, Iran. Boll weight was determined from 20 hand-harvested bolls, just prior to first harvest from each plot. Seed cotton yield was determined by hand harvest. Plant height was measured from ground level to the top of the plant at harvest time. Monopodia and sympodia branch length, monopodia and sympodia branches/plant was measured prior to first harvest.

The data for each measurement was tabulated and analyzed by Fisher's analysis of variance. The diallel analysis was 
used to evaluate traits that had significant variation among the parents. Griffing-type diallel analysis was applied to estimate the GCA and SCA effects.

\section{Results}

Preliminary analysis of variance indicated that parents and their hybrids were significantly different from each other for all investigated traits in the study, which enable the diallel analysis to be run (Table 1).

\subsection{Female parents different}

The four parents used in this study varied significantly for each components and agro morphological traits except for sympodia and monopodia branch length (Table 2). Termeze 14 had the highest values in height characters. About boll/plant, barbadense 5539 and Termeze 14 had the highest value. The maximum monopodia branch number/plant was for Sahel and Sepid cultivars. Termeze 14 and barbadense 5539 had the highest values in sympodia branch/plant. The monopodia and sympodia branch length were not significantly difference in female parents. Sahel and Sepid (G. hirsutum spesies) had the weightiest boll. These, also, had the highest values for yield.

\subsection{Male parent's difference}

The genotypes used for male parents were significantly different for each yield components and agro morphological traits except for boll/plant and boll weight characters. Barbadense 5539 had the highest value for height. G. hirsutum species, Sahel and Sepid, had the maximum monopodia branch/plant and minimum sympodia branch/plant. The highest sympodia branch length was for Sahel cultivar. Barbadense 5539 had the lowest monopodia branch length. Sepid had the highest value for seed cotton yield.

\subsection{F1 performance}

The data in Table 3 were significantly difference for each yield components and agro morphological traits for F1 hybrids used in this study. Sahel $\times$ barbadense 5539 hybrid had the highest value for height $(170 \mathrm{Cm})$. Sahel $\times$ Sahel had the lowest height $(114 \mathrm{Cm})$. Bolls/plant were significantly different among the genotypes, where barbadense $5539 \times$ Sahel (37.5), barbadense 5539×Termeze 14 (38.3), Termeze $14 \times$ barbadense 5539 (35.4) and Termeze $14 \times$ Termeze 14 (35.1) crosses had many bolls, while Sahel $\times$ Sepid (19.13) hybrid had significantly lower numbers of boll/plant. Among the crosses, Sepid $\times$ Sepid had the highest values for monopodia branch number/plant, also, Sahel $\times$ barbadense 5539 (20.1), barbadense 5539×barbadense5539 (19.8), barbadense 5539×Termeze 14 (19.7) and Termeze 14×barbadense 5539 (20.1) crosses had the highest sympodia branch number/plant. Sympodia branch length in Termeze $14 *$ Sahel crosses was the highest $(62.9 \mathrm{Cm})$. Sahel $\times$ Termeze $14(98.5 \mathrm{Cm})$ and Termeze $14 \times$ Sahel $(102.7 \mathrm{Cm})$ had the highest value for monopodia branch length. Sahel $\times$ Sepid (128.0 gr) and Sepid $\times$ Sahel $(133.1 \mathrm{gr})$ crosses had the weightiest boll and Termeze $14 \times$ Sepid crosses had the lowest boll. Sepid $\times$ Sahel crosses had the highest yield/plot (4977 gr) and Termeze $14 \times$ Sahel had the lowest yield/plot (2195 gr).

\subsection{Agro morphological GCA and SCA}

Analysis of variance for genotypes indicated the presence of significant differences among genotypes (Table 4). Combining ability mean squares for the characteristics are presented in Table 4. Significant GCA mean squares for yield components, height, bolls/plant, monopodia branches/plant, sympodia branches/plant, monopodia and sympodia branch length, boll weight and seed cotton yield indicated that additive genes controlled most of the characteristics. GCA mean square values were higher compared to the mean squares for SCA except for sympodia branch length (Table 4).

Results for GCA effects are given in Table 6. Sahel had negative GCA effects for height, bolls/plant, sympodia branches/plant and yield. Sahel, known to have big bolls, had positive and significant GCA effects for boll weight, monopodia branches/plant, sympodia and monopodia branch length. GCA effects for barbadense 5539 on height, bolls/plant and sympodia branches/plant were positive. GCA effects for sympodia branches/plant, sympodia and monopodia branch length, boll weight and yield were negative at Hashemabad research station (Table 6). The GCA effect for Sepid cultivar was positive for monopodia branches/plant, sympodia and monopodia branch length, boll weight and yield. Negative GCA effects were observed for bolls/plant, height, sympodia branches/plant. Positive GCA effects were shown by Termeze 14 genotype for height, bolls/plant, sympodia branches/plant and monopodia branch length while the values for monopodia branches/plant, sympodia branch length, boll weight and yield were negative.

SCA effect estimates for height, bolls/plant, sympodia branches/plant, monopodia branches/plant, sympodia branch length, monopodia branch length, boll weight and yield are presented in Table 7. SCA effects for some characteristics indicated variation among F1 hybrids. For height, three combinations had positive SCA effects. Four combinations had positive SCA effect for bolls/plant, sympodia branches/plant, sympodia and monopodia branch length. For monopodia branches/plant, five combinations had positive SCA effects. Sahel $\times$ Sahel, Sahel $\times$ Sepid, barbadense $5539 \times$ barbadense 5539, barbadense 5539 $\times$ Termeze14 and Termeze14 $\times$ Termeze14 had positive SCA effects for boll weight. Sahel $\times$ Sahel, Sahel $\times$ barbadense 5539 , Sahel $\times$ Sepid, Sahel $\times$ Termeze 14 , barbadense $5539^{*}$ barbadense 5539 , barbadense $5539 \times$ Sepid had the positive SCA effects for seed cotton yield (Table 7). 


\subsection{Cytoplasmic effects}

Results for cytoplasmic effects are given in Table 8 . Sahel $\times$ barbadense 5539 and barbadense $5539 \times$ Sepid combinations had positive effect. For height, positive maternal effect was showed at barbadense $5539 \times$ Sepid crosses. Barbadense5539 $\times$ Termeze 14 combinations had positive maternal effect for bolls/plant. Maternal effect was positive for monopodia branches/plant at barbadense $5539 \times$ Termeze 14 crosses. About sympodia branches/plant Sahel $\times$ barbadense5539, barbadense $5539 \times$ Sepid and Sepid $\times$ Termeze14 had positive maternal effects. Positive cytoplasmic effects were observed for sympodia branch length at barbadense $5539 \times$ Sepid crosses. The observed maternal effect for boll weight, Sahel $\times$ Termeze14 and barbadense $5539 \times$ Termeze14 combinations were positive. For seed cotton yield, Sahel×barbadense 5539 and Sahel $\times$ Termeze14 had the positive cytoplasmic effect (Table 8 ).

\subsection{Heterosis estimates}

Heterosis values for the combination varied from negative to positive (Table 5). Height heterosis was positive for all of the combinations. Sahel $\times$ Termeze 14 had high positive heterosis. Heterosis values for bolls/plant were positive for most of the combinations except for Sahel $\times$ Sepid and Sahel $\times$ Termeze14, and Sahel $\times$ barbadense 5539 combination had the highest heterosis (6.83). The heterosis value for monopodia branches/plant for all combinations except for Sahel $\times$ Termeze14 was negative. Heterosis estimates recorded on combinations for sympodia branches/plant varied from negative to positive. Sahel $\times$ barbadense 5539 had the highest heterosis value, Also Sahel $\times$ Termeze14 had the highest heterosis value for sympodia and monopodia branch length, When G. hirsutum and G. barbadense species were crossed, heterosis was positive. In this study, Sahel $\times$ Sepid had the maximum heterosis for boll weight. Heterosis values for seed cotton yield were positive for most of the combinations, except for Sahel $\times$ Termeze14 and Sahel $\times$ barbadense5539. The high heterosis value were obtained in Sahel $\times$ Sepid (345.83, G. hirsutum $\times$ G. hirsutum) and Sepid $\times$ Termzeze14 (758.33, G. hirsutum $\times$ G. barbadense).

\section{Discussion}

High variation was observed for characteristics among parents and the F1 combinations. So, selection could be done for improved yield, yield components and agro morphological traits. GCA values obtained for Sahel, barbadense5539, Sepid and Termeze14 indicated the possibility of good combining from these parents for the some traits. Barbadense5539 and Termzeze14 (G. barbadense) had positive GCA for height, bolls/plant and sympodia branches/plant, inverse Sahel and sepid (G. hirsutum) had negative GCA for these characteristics. G. barbadense genotypes were showed negative GCA effect for monopodia branches/plant, sympodia branch length and boll weight, inverse G. hirsutum genotypes were observed positive GCA for these traits. Positive GCA for yield was observed only in Sepid. Positive SCA effects observed for same crosses. Sahel $\times$ barbadense 5539 crosses had the highest positive SCA for bolls/plant. Highest positive SCA was observed for boll weight in Sahel $\times$ Sepid. In Sahel $\times$ Sahel, highest positive SCA was showed for yield.

Significant SCA mean squares observed for boll weight was reported by Echekwu and Alaba (1995). The performance of some combinations indicated the possibility of improvement of these traits. Griffing (1956) and Machado et al. (2002) reported that crosses with high SCA values from parents with highest SCA in a population should be efficient in selection in segregation population. The high and significant positive GCA were observed in crosses for seed cotton yield, lint yield, seed/boll, bolls/plant and boll weight (Lukonge, 2005).

The GCA:SCA ratios for the studied traits were higher than one indicating the presence of additive genetic effects for most of the characteristics studied except for sympodia branch length. According to Ashraf and Ahmad (2000), high additive genetic variation for these characteristics suggested a possibility of improvement in these characteristics. Therefore normal recurrent selection would be required to accumulate the additive genes in order to increase seed cotton yield (Lukonge, 2005).

Positive heterosis for height was observed for all of combinations. Positive heterosis for boll weight was showed in Sahel $\times$ Sepid, barbadense $5539 \times$ Sepid and Sepid $\times$ Termeze14. Sambamurthy et al. (1995) reported that in tetraploid cotton, boll weight and boll number for intraspecific hybrids are the major components of heterosis in yield and this usually observed in G. hirsutum crosses and not for G. barbadense. The highest positive heterosis for yield was observed in Sepid $\times$ Termeze14 and Sahel $\times$ Sepid. Xian et al. (1995) and Zhang and Zhang (1997) reported high heterosis for seed cotton and lint yield. Sahel $\times$ barbadense 5539 had the highest reciprocal effects for height and yield. For bolls/plant, barbadense $5539 \times$ Sepid had the high positive reciprocal effects. High positive reciprocal effects for boll weight was showed in Sahel×Termeze14.

Gossypium hirsutum and G. barbadense differ significantly in their agronomic and fiber traits (Percey et al, 2006).G. hirsutum had the higher yield potential and G. barbadense had the best fiber quality. Interspecific hybridization and introgression, G. hirsutum and G. barbadense, has led to improve lines with the higher yield and the best fiber qualities. Efforts to improve G. hirsutum or G. barbadense through introgression have been hindered by genetic breakdown in segregating interspecific breeding populations (Stephens, 1949). Genetically stable lines have been developed after 
multiple cycles of breeding and selection (Tatineni et al., 1996; Cantrell and Davis, 1993). We consider commercial interspecific hybrids (F1) to cultivate in cotton farms in different region of Iran. We hope to improve and develop stable lines of interspecific crosses (Gossypium hirsutum and G. barbadense) and intraspecific crosses (G. hirsutum $\times$ G. hirsutum, and G. barbadense $\times$ G. barbadense) after lengthy cycles of selection.

\section{References}

Ashraf, M. \& Ahmad, s. (2000). Genetic effects for yield components and fiber characteristics in upland cotton (Gossypium hirsutum L.) cultivated under salinized ( $\mathrm{NaCl}$ conditions), Agronomie, 20: 917-926.

Baloch, M. J., Bhutto, H., Rind, R. \& Tunio, G. H. (1995). Combining ability estimates in $5 * 5$ diallel intra-hirsutum crosses. Pakistan Journal of Botany, 27: 121-126.

Bell, A. A. \& Robinson, A. F. (2004). Development and characteristics of triple species hybrids used to transfer reniform nematode resistance from Gossypium longicalyx to Gossypium hirsutum. P.422-426. In proceeding Beltwide cotton cotton conference, San Antonio, TX. 5-9 Jan. 2004. Natl. Cotton Council of American, Memphis, TN.

Cantrell, R. G. \& Davis, D. D. (1993). Characterization of Upland $\times$ Pima breeding lines using molecular markers. P. 1551-1553. Proceeding Beltwide Cotton Conference, New Orleans, LA. 10-14 Jan. 1993. Natl. Cotton Council American, Memphis TN.

Echekwu, C. A. \& Alaba, S. O. (1995). Genetic effects of yield and its components in interspecific crosses of cotton. Discovery and Innovation, 7: 395-399.

Fryxell, P. A., Staten, G., \& Porter, J. H. (1958). Performance of some wide crosses in gossypium. N. Mex. Agr. Expt. Sta. Bul. 419, 15 pp.

Fryxell, P. A. (1979). The natural history of the cotton tribe. Texas A\& M University Press, College Station, Texas.

Griffing, B. (1956). Concept of general and specific combining ability in relation to diallel crossing systems. Australian Journal of Biological Science, 9: 463-493.

Gutierrez, O. A., Basu., S., Saha, S., Jenkins, J. N., Shoemaker D. B., Cheatham, C. L. \& McCarty, Jr. J. C. ( 2002). Genetic Distance among Selected Cotton Genotypes and Its Relationship with F2 Performance. Crop Science, 44: 1841-1847.

Lacape., J. M., Nguyen, T. B., Courtois, B., Belot, J. L., Giband, M., Gourlot, J. P., Gawryziak, G., Roques, S. \& Hau, B.( 2005). QTL analysis of cotton fiber quality using multiple Gossypium hirsutum $\times$ Gossypium barbadense backcross generations. Crop Science, 45: 123-140.

Lunkonge, E. P. (2005). Characterization and diallel analysis of commercially planted cotton ( Gossypium hirsutum L.) germplasm in Tanzania. Submitted in the fulfillment of the requirements for the degree of philosophiae doctor. University of the Free State, South Africa.

Machado, C. F., Santos, J. B., Nunes,a G. H. \& Ramalho, M. A. P. (2002). Choice of common bean parents based on combining ability estimates. Genetics and Molecular Biology, 25: 179-183.

Marani, A. (1967). Heterosis and combining ability in intraspecific and interspecific crosses of cotton. Crop Science, 7 : 519-522.

Nadeem, A., Munir, D. K., Khan, M. A., Mushtag, A., Austain, N. \& Ahmad, M. (1998). Genetic studies of cotton (Gossypium hirsutum L.). 1. Combining ability and heterosis studies in yield and yield components. Pakistan Journal of Scientific and Industrial Research, 41: 54-56.

Percy, R. G., Cantrell, R. G. \& Zhang, J. (2006). Genetic variation for agronomic and fiber properties in an introgressed recombinant inbred population of cotton. Crop science, 46: 1311-1317.

Poehlman, J.M. \& Sleper, D. A. (1995). Breeding field crops. Fourth edition. Iowa State University Press, USA. P: 494.

Robinson, A.F., Bell, A. A., Dighe, N. D., Menz, M. A., Nichols, R. L. \& Stelly, D. M. (2007). Introgression of resistance to nematode Rotylenchulus reniformis into upland cotton (Gossypium hirsutum) from Gossypium longicalyx. Crop Science, Vol.47. 1865-1877.

Saha. S., Jenkins, J. N., Wu, J., Mccarty, J. C., Gutierrez, O. A., Percy, R. G., Cantrell, R. G. \& Stelly, D. M. (2006). Effects of chromosome-specific introgression in upland cotton on fiber and agronomic traits. Genetics, 172: 1927-1938.

Sambamurthy, J. S. V., Reddy, D. M. \& reddy, K.H.G. (1995). Studies on the nature of genetic divergence in upland cotton (Gossypium hirsutum L.). Annals of agricultural Research, 16: 307-310.

Shappley, Z. W., Jenkins, J. N., Zhu, J. \& Mccarty, Jr., J. C. (1998). Quantitative trait loci associated with agronomic and fiber traits of upland cotton. The Journal of Cotton Science, 2: 153-163.

Smith, W. C. (1999). Production statistics. In Smith, W. C. and J. T. Cothern (eds.). Cotton: origin, history, technology, 
and production. John Wiley and Sons, Inc. New York.

Stephens, S. C. (1949). The cytogenetics of speciation in Gossypium. I. Selective elimination of the donor parent genotype in interspecific backcrosses. Genetics, 34: 627-637.

Stroman, G. N. (1961). AN APPROACH TO HYBRID COTTON AS SHOWN BY INTRA AND INTERSPECIFIC CROSSES. Crop Sci., 1: 363-366.

Tang, B., Jenkins, J.N., McCarty, J.C. \& Watson, C. E. (1993). F2 hybrids of host plant germplasm and cotton cultivars:II. Heterosis and combining ability for lint yield and yield components. Crop science, 33: 700-705.

Tatineni, V., Cantrell, R. G. \& Davis, D. D. (1996). Genetic diversity in elite cotton germplasm determined by morphological characteristics and RAPDs. Crop Science, 36: 186-192.

Ulloa, M. \& Meredith, Jr., W. R. (2000). Genetic linkage map and QTL analysis of agronomic and fiber quality traits in interspecific population. The Journal of Cotton Science, 4: 161-170.

Vafaie-tabar., M., Chndrashekaran, S., Rana, M. K. \& Bhat, K.V. (2004). RAPD analysis of genetic diversity in Indian tetraploid and diploid cotton (Gossypium spp). Journal of Plant Biochemistry \& Bioteechnology, 13: 81-84.

Wang, G. L., Dong, J. M. \& Paterson, A. H. (1995). The distribution of Gossypium hirsutum chromatin in G. barbadense germ plasm: molecular analysis of introgressive plant breeding. Theoretical and Applied Genetics, 91: 1153-1161.

Wendel, J. F., Olson, P. D. \& Stewart, J. M. D. (1989). Genetic diversity, introgression and independent domestication of old world cultivated cottons. American Journal of Botany, 76: 1793-1806.

Wilson, F. D. (1991). Combining ability for yield characteristics and earliness of pink bollworm-resistant cotton. Crop Science, 31:922-925.

Xian, X. X., Wang, X., Yin, Z. \& Xie, L. (1995). Analysis of combining ability and heterosis for parental varieties in upland cotton. Journal of Hebei Agricultural University, 18: 34-40.

Zhang, X. L. \& Zhang, X. L. (1997). Prediction and utilization of hybrid heterosis between dominant glandless lines and conventional cotton varieties. China Cottons, 24: 20-21.

Table 1. Mean squares of yield components and agro morphological traits

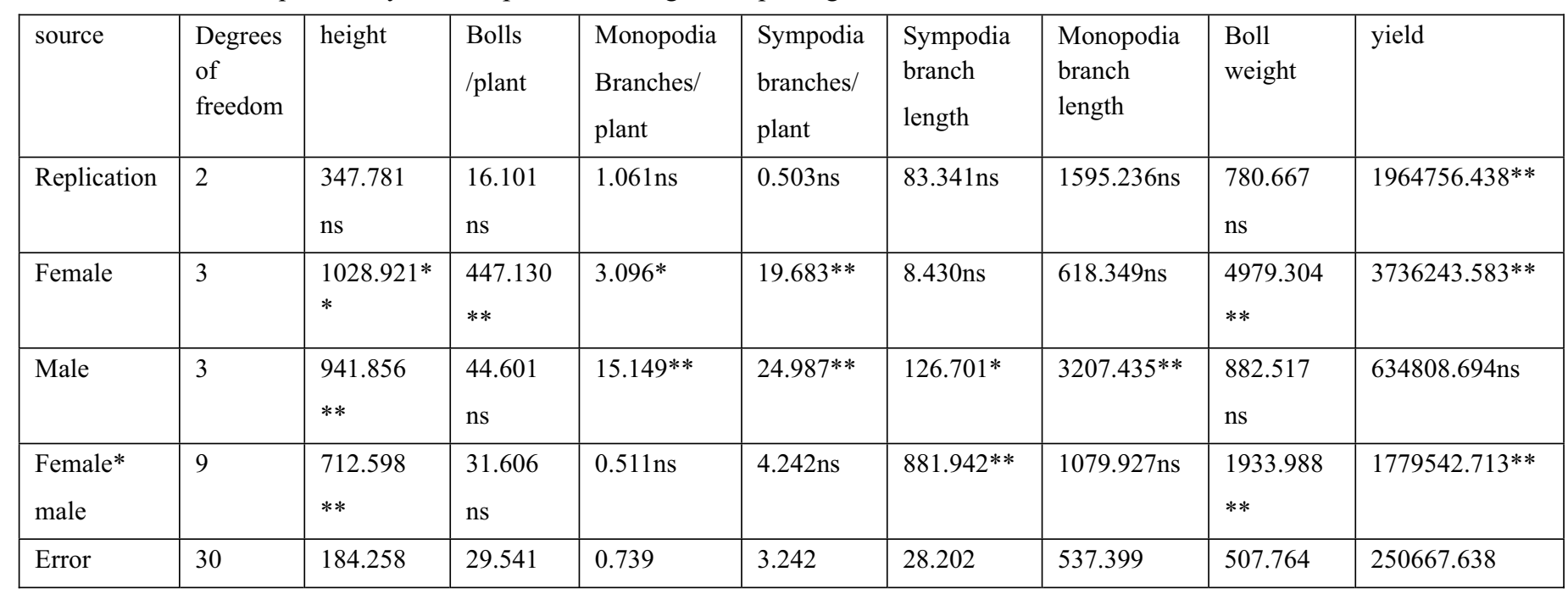

**: significant at 0.01 level, *: significant at 0.05 level and ns: non significant 
Table 2. Means of yield components and agro morphological traits for female and male parents

\begin{tabular}{|l|l|l|l|l|l|l|l|l|}
\hline & height & Bolls/plant & $\begin{array}{l}\text { Monopodia } \\
\text { Branches/plant }\end{array}$ & $\begin{array}{l}\text { Sympodia } \\
\text { branches/plant }\end{array}$ & $\begin{array}{l}\text { Sympodia } \\
\text { branch } \\
\text { length }\end{array}$ & $\begin{array}{l}\text { Monopodia } \\
\text { branch } \\
\text { length }\end{array}$ & $\begin{array}{l}\text { Boll } \\
\text { weight }\end{array}$ & yield \\
\hline Female & & & & & & & & \\
\hline Sahel & $137.08 \mathrm{bc}$ & $24.33 \mathrm{~b}$ & $2.417 \mathrm{a}$ & $16.42 \mathrm{~b}$ & $43.37 \mathrm{a}$ & $69.98 \mathrm{a}$ & $90.04 \mathrm{a}$ & $3482 \mathrm{~b}$ \\
\hline Barbadense5539 & $147.28 \mathrm{ab}$ & $35.73 \mathrm{a}$ & $1.433 \mathrm{~b}$ & $19.08 \mathrm{a}$ & $41.92 \mathrm{a}$ & $58.28 \mathrm{a}$ & $58.64 \mathrm{~b}$ & $3215 \mathrm{~b}$ \\
\hline Sepid & $129.97 \mathrm{c}$ & $24.38 \mathrm{~b}$ & $2.583 \mathrm{a}$ & $16.70 \mathrm{~b}$ & $41.40 \mathrm{a}$ & $74.20 \mathrm{a}$ & $99.25 \mathrm{a}$ & $4359 \mathrm{a}$ \\
\hline Termeze 14 & $149.98 \mathrm{a}$ & $33.98 \mathrm{a}$ & $2.100 \mathrm{ab}$ & $18.32 \mathrm{a}$ & $42.03 \mathrm{a}$ & $72.47 \mathrm{a}$ & $61.41 \mathrm{~b}$ & $3147 \mathrm{~b}$ \\
\hline Male & & & & & & & & \\
\hline Sahel & $136.25 \mathrm{~b}$ & $28.32 \mathrm{a}$ & $3.000 \mathrm{a}$ & $16.47 \mathrm{~b}$ & $46.37 \mathrm{a}$ & $78.98 \mathrm{a}$ & $85.29 \mathrm{a}$ & $3497 \mathrm{ab}$ \\
\hline Barbadense5539 & $153.37 \mathrm{a}$ & $31.00 \mathrm{a}$ & 0.817 & $19.37 \mathrm{a}$ & $39.53 \mathrm{~b}$ & $45.08 \mathrm{~b}$ & $65.41 \mathrm{a}$ & $3498 \mathrm{ab}$ \\
\hline Sepid & $133.27 \mathrm{~b}$ & $27.62 \mathrm{a}$ & $3.133 \mathrm{a}$ & $16.42 \mathrm{~b}$ & $43.13 \mathrm{ab}$ & $80.32 \mathrm{a}$ & $81.22 \mathrm{a}$ & $3876 \mathrm{a}$ \\
\hline Termeze 14 & $141.43 \mathrm{~b}$ & $31.50 \mathrm{a}$ & $1.583 \mathrm{~b}$ & $18.27 \mathrm{a}$ & $39.68 \mathrm{~b}$ & $70.55 \mathrm{a}$ & $77.42 \mathrm{a}$ & $3333 \mathrm{~b}$ \\
\hline
\end{tabular}

* Means within columns followed by the same letter(s) are not different at 0.05 probability level

Table 3. Means of yield components and agro morphological traits for hybrid combinations

\begin{tabular}{|c|c|c|c|c|c|c|c|c|}
\hline & height & Bolls/plant & $\begin{array}{l}\text { Monopodia } \\
\text { Branches/plant }\end{array}$ & $\begin{array}{l}\text { Sympodia } \\
\text { branches/plant }\end{array}$ & $\begin{array}{l}\text { Sympodia } \\
\text { branch } \\
\text { length }\end{array}$ & $\begin{array}{l}\text { Monopodial } \\
\text { branch } \\
\text { length }\end{array}$ & $\begin{array}{l}\text { Boll } \\
\text { weight }\end{array}$ & yield \\
\hline Sahel $\times$ Sahel & $114.0 \mathrm{~g}$ & $22.5 \mathrm{cde}$ & $2.933 \mathrm{abc}$ & $14.7 \mathrm{~cd}$ & $32.3 \mathrm{~d}$ & 67.0abcde & $101.2 \mathrm{ab}$ & $4440 \mathrm{ab}$ \\
\hline Sahel $\times$ Barbadense5539 & $170.6 \mathrm{a}$ & $31.5 \mathrm{abcd}$ & $0.933 \mathrm{defg}$ & $20.1 \mathrm{a}$ & $53.2 \mathrm{abc}$ & $51.7 \mathrm{bcde}$ & $58.6 \mathrm{bcd}$ & 2960 efgh \\
\hline Sahel $\times$ Sepid & $115.1 \mathrm{fg}$ & $19.1 \mathrm{e}$ & $3.400 \mathrm{ab}$ & $13.8 \mathrm{~d}$ & $31.8 \mathrm{~d}$ & $62.7 \mathrm{abcde}$ & $128.0 \mathrm{a}$ & $4205 \mathrm{abc}$ \\
\hline Sahel $\times$ Termeze14 & $148.7 \mathrm{abcd}$ & $24.1 \mathrm{bcde}$ & $2.400 \mathrm{abcd}$ & 17.1 abcd & $56.1 \mathrm{abc}$ & $98.5 \mathrm{a}$ & $72.3 \mathrm{bcd}$ & $2325 \mathrm{gh}$ \\
\hline Barbadense $5539 \times$ Sahel & 144.5abcde & $37.5 \mathrm{a}$ & $2.267 \mathrm{bcde}$ & $18.4 \mathrm{ab}$ & $57.6 \mathrm{ab}$ & 65.0abcde & $45.5 \mathrm{~cd}$ & $2378 \mathrm{fgh}$ \\
\hline $\begin{array}{l}\text { Barbadense } 5539 \times \\
\text { Barbadense } 5539\end{array}$ & 151.9abcd & $32.9 \mathrm{abc}$ & $0.733 \mathrm{efg}$ & $19.8 \mathrm{a}$ & $25.3 \mathrm{~d}$ & $44.7 \mathrm{cde}$ & $43.0 \mathrm{~cd}$ & $3260 \mathrm{cdef}$ \\
\hline Barbadense $5539 \times$ Sepid & $146.2 \mathrm{abcd}$ & $34.3 \mathrm{ab}$ & $2.133 \mathrm{bcdef}$ & $18.4 \mathrm{ab}$ & $59.9 \mathrm{ab}$ & $85.7 \mathrm{abc}$ & $65.2 \mathrm{bcd}$ & $3630 \mathrm{bcde}$ \\
\hline $\begin{array}{l}\text { Barbadense5539× } \\
\text { Termeze14 }\end{array}$ & $146.5 \mathrm{abcd}$ & $38.3 \mathrm{a}$ & $0.600 \mathrm{fg}$ & $19.7 \mathrm{a}$ & $24.9 \mathrm{~d}$ & $37.7 \mathrm{de}$ & $80.9 \mathrm{bc}$ & $3592 \mathrm{bcde}$ \\
\hline Sepid $\times$ Sahel & $125.7 \mathrm{defg}$ & $22.3 \mathrm{de}$ & $3.533 \mathrm{ab}$ & $15.5 \mathrm{bcd}$ & $32.7 \mathrm{~d}$ & $81.2 \mathrm{abcd}$ & $133.1 \mathrm{a}$ & $4977 \mathrm{a}$ \\
\hline Sepid $\times$ Barbadense 5539 & $133.8 \mathrm{cdefg}$ & $24.2 \mathrm{bcde}$ & $1.133 \mathrm{defg}$ & $17.5 \mathrm{abc}$ & $52.8 \mathrm{bc}$ & $58.5 \mathrm{abcde}$ & $80.8 \mathrm{bc}$ & $4132 \mathrm{abc}$ \\
\hline Sepid $\times$ Sepid & $120.3 \mathrm{efg}$ & $22.6 \mathrm{cde}$ & $4.000 \mathrm{a}$ & $15.3 \mathrm{bcd}$ & $33.3 \mathrm{~d}$ & $81.5 \mathrm{abcd}$ & $97.8 \mathrm{ab}$ & $4050 \mathrm{abcd}$ \\
\hline Sepid $\times$ Termeze14 & $140.0 \mathrm{bcdef}$ & $28.5 \mathrm{abcde}$ & $1.667 \mathrm{cdefg}$ & $18.5 \mathrm{ab}$ & $46.9 \mathrm{c}$ & 75.6abcd & $85.3 \mathrm{bc}$ & $4278 \mathrm{ab}$ \\
\hline Termeze $14 \times$ Sahel & $160.7 \mathrm{ab}$ & 30.9abcd & $3.267 \mathrm{abc}$ & $17.3 \mathrm{abc}$ & $62.9 \mathrm{a}$ & $102.7 \mathrm{a}$ & $61.4 \mathrm{bcd}$ & $2195 \mathrm{~h}$ \\
\hline $\begin{array}{l}\text { Termeze14× } \\
\text { Barbadense5539 }\end{array}$ & $157.2 \mathrm{abc}$ & $35.4 \mathrm{a}$ & $0.467 \mathrm{~g}$ & $20.1 \mathrm{ab}$ & $26.9 \mathrm{~d}$ & $25.5 \mathrm{e}$ & $79.2 \mathrm{bc}$ & $3638 \mathrm{bcde}$ \\
\hline Termeze14× Sepid & $151.5 \mathrm{abcd}$ & $34.5 \mathrm{ab}$ & $3.000 \mathrm{abc}$ & $18.2 \mathrm{ab}$ & $47.6 \mathrm{c}$ & $91.3 \mathrm{ab}$ & $33.9 \mathrm{~d}$ & $3618 \mathrm{bcde}$ \\
\hline Termeze14×Termeze14 & $130.5 \mathrm{defg}$ & $35.1 \mathrm{a}$ & $1.667 \mathrm{cdefg}$ & $17.7 \mathrm{abc}$ & $30.8 \mathrm{~d}$ & $70.4 \mathrm{abcd}$ & $71.2 \mathrm{bcd}$ & 3137defg \\
\hline
\end{tabular}

* Means within columns followed by the same letter(s) are not different at 0.05 probability level 
Table 4. Mean squares for yield and agro morphological GCA, SCA and GCA: SCA ratio for cotton genotypes

\begin{tabular}{|l|l|l|l|l|l|l|l|l|l|}
\hline source & d.f. & height & Bolls/plant & $\begin{array}{l}\text { Monopodia } \\
\text { Branches } \\
\text { plant }\end{array}$ & $\begin{array}{l}\text { Sympodia } \\
\text { branches/plant }\end{array}$ & $\begin{array}{l}\text { Sympodia } \\
\text { branch } \\
\text { length }\end{array}$ & $\begin{array}{l}\text { Monopodia } \\
\text { branch } \\
\text { length }\end{array}$ & Boll weight & yield \\
\hline Rep & 2 & $347.781 \mathrm{~ns}$ & $16.101 \mathrm{~ns}$ & $1.061 \mathrm{~ns}$ & $0.466 \mathrm{~ns}$ & $83.341 \mathrm{~ns}$ & $1595.236 \mathrm{~ns}$ & $71.183 \mathrm{~ns}$ & $2.956 \mathrm{e}+006^{* *}$ \\
\hline genotypes & 15 & $821.714^{* *}$ & $117.310^{* *}$ & $3.956^{* *}$ & $11.464^{* *}$ & $556.192^{* *}$ & $1413.113^{*}$ & $1451.711^{* *}$ & $1.918 \mathrm{e}+006^{* *}$ \\
\hline GCA & 3 & $1727.389^{* *}$ & $381.946^{* *}$ & $15.664^{* *}$ & $44.465^{* *}$ & $88.716^{*}$ & $3233.130^{* *}$ & $3469.292^{* *}$ & $3.663 \mathrm{e}+006^{* *}$ \\
\hline SCA & 6 & $856.122^{* *}$ & $42.899 \mathrm{~ns}$ & $0.721 \mathrm{~ns}$ & $4.802 \mathrm{~ns}$ & $1316.205^{* *}$ & $1497.564^{*}$ & $1778.966^{* *}$ & $2.726 \mathrm{e}+006^{* *}$ \\
\hline Recip & 6 & $334.469 \mathrm{~ns}$ & $59.403 \mathrm{~ns}$ & $1.336 \mathrm{~ns}$ & $1.627 \mathrm{~ns}$ & $29.916 \mathrm{~ns}$ & $418.653^{* *}$ & $115.666 \mathrm{~ns}$ & $238401.389 \mathrm{~ns}$ \\
\hline Error & 30 & 184.258 & 29.541 & 0.739 & 3.373 & 28.202 & 537.399 & 220.758 & 241021.840 \\
\hline $\begin{array}{l}\text { GCA: } \\
\text { SCA }\end{array}$ & & 2.02 & 8.9 & 21.7 & 9.2 & 0.07 & 2.2 & 2 & 1.3 \\
\hline
\end{tabular}

$\mathrm{GCA}=$ General combining ability, $\mathrm{SCA}=$ Specific combining ability, $\mathrm{df}=$ degree of freedom

Table 5. Mean mid-parent heterosis for yield and agro morphological traits

\begin{tabular}{|l|l|l|l|l|l|l|l|l|l|}
\hline Female & male & height & $\begin{array}{l}\text { Bolls } \\
\text { plant }\end{array}$ & $\begin{array}{l}\text { Monopodia } \\
\text { Branches } \\
\text { /plant }\end{array}$ & $\begin{array}{l}\text { Sympodia } \\
\text { Branches } \\
\text { /plant }\end{array}$ & $\begin{array}{l}\text { Sympodia } \\
\text { branch length }\end{array}$ & $\begin{array}{l}\text { Monopodia } \\
\text { branch } \\
\text { length }\end{array}$ & $\begin{array}{l}\text { Boll } \\
\text { weight }\end{array}$ & $\begin{array}{l}\text { yield } \\
\text { Sahel }\end{array}$ \\
\hline & Barbadense \\
5539 & 24.63 & 6.83 & -0.23 & 2.0 & 26.60 & 2.53 & -23.17 & -1207.50 \\
\hline Sahel & Sepid & 3.23 & -1.87 & 0 & -0.33 & -0.57 & -2.30 & 31.07 & 345.83 \\
\hline Sahel & Termeze14 & 32.43 & -1.30 & 0.53 & 1.03 & 27.93 & 31.90 & -19.37 & -1528.33 \\
\hline $\begin{array}{l}\text { Barbadense } \\
5539\end{array}$ & Sepid & 3.90 & 1.50 & -0.73 & 0.43 & 27.07 & 9.00 & -10.65 & 36.67 \\
\hline $\begin{array}{l}\text { Barbadense } \\
5539\end{array}$ & Termeze14 & 10.67 & 2.87 & -0.67 & 1.17 & -2.13 & -25.93 & 9.72 & 227.50 \\
\hline Sepid & Termeze14 & 20.30 & 2.60 & -0.50 & 1.87 & 15.20 & 7.47 & 2.92 & 758.33 \\
\hline
\end{tabular}

Table 6. General combining ability (GCA) effects of yield and agro morphological traits

\begin{tabular}{|l|l|l|l|l|l|l|l|l|}
\hline Genotypes & height & Bolls/plant & $\begin{array}{l}\text { Monopodia } \\
\text { Branches/plant }\end{array}$ & $\begin{array}{l}\text { Sympodia } \\
\text { branches/plant }\end{array}$ & $\begin{array}{l}\text { Sympodia } \\
\text { branch } \\
\text { length }\end{array}$ & $\begin{array}{l}\text { Monopodia } \\
\text { branch } \\
\text { length }\end{array}$ & $\begin{array}{l}\text { Boll } \\
\text { weight }\end{array}$ & $\begin{array}{l}\text { yield } \\
\text { Sahel }\end{array}$ \\
\hline Barbadense5539 & -4.41 & -3.28 & 0.58 & -1.19 & 2.69 & 5.75 & 6.47 & -114.69 \\
\hline Sepid & -9.46 & -3.61 & 0.72 & 1.60 & -1.45 & -17.05 & -12.52 & -153.85 \\
\hline Termeze 14 & 4.63 & 3.1 & -0.29 & -1.07 & 0.09 & 8.52 & 13.44 & 573.02 \\
\hline
\end{tabular}


Vol. 2, No. 1

Table 7. Specific combining ability (SCA) effects for yield and agro morphological traits

\begin{tabular}{|c|c|c|c|c|c|c|c|c|c|}
\hline Female & Male & height & Bolls/plant & $\begin{array}{l}\text { Monopodia } \\
\text { Branches/plant }\end{array}$ & $\begin{array}{l}\text { Sympodia } \\
\text { branches/plant }\end{array}$ & $\begin{array}{l}\text { Sympodia } \\
\text { branch } \\
\text { length }\end{array}$ & $\begin{array}{l}\text { Monopodia } \\
\text { branch } \\
\text { length }\end{array}$ & $\begin{array}{l}\text { Boll } \\
\text { weight }\end{array}$ & yield \\
\hline Sahel & Sahel & -18.25 & -0.51 & -0.35 & -0.58 & -15.22 & -13.23 & 4.55 & 1024.06 \\
\hline Sahel & Barbadense 5539 & 11.65 & 4.45 & -0.10 & 1.20 & 11.99 & 0.93 & -15.46 & 487.19 \\
\hline Sahel & Sepid & -6.80 & -2.02 & 0.03 & -0.73 & -12.72 & -11.04 & 26.91 & 437.81 \\
\hline Sahel & Termeze 14 & 13.40 & -1.92 & 0.42 & 0.11 & 15.95 & 23.34 & -16.00 & 428.02 \\
\hline Barbadense5539 & Barbadense5539 & -7.70 & -4.26 & 0.62 & -1.03 & -14.00 & 10.03 & 10.87 & 300.73 \\
\hline Barbadense5539 & Sepid & -0.86 & -0.52 & -0.22 & -0.19 & 15.52 & 11.89 & -11.64 & 100.31 \\
\hline Barbadense5539 & Termeze 14 & -3.09 & 0.33 & -0.30 & 0.02 & -13.50 & -22.86 & 16.24 & -183.64 \\
\hline Sepid & Sepid & -1.82 & 0.21 & 0.42 & -0.21 & -9.09 & -4.25 & -12.85 & -545.10 \\
\hline Sepid & Termeze 14 & 9.49 & 2.33 & -0.23 & 1.13 & 6.29 & 3.40 & -2.42 & -741.35 \\
\hline Termeze 14 & Termeze 14 & -19.80 & -0.74 & 0.12 & -1.26 & -8.74 & -3.88 & 2.18 & -966.14 \\
\hline
\end{tabular}

Table 8. Reciprocal effects for yield and agro morphological traits

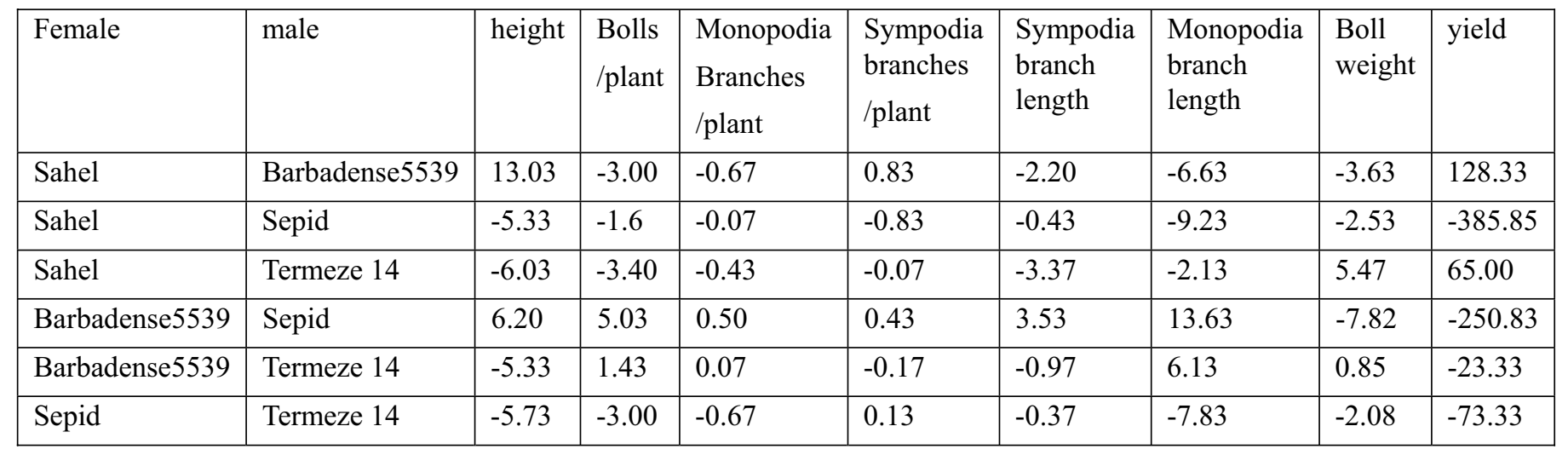

